\title{
Relationship between grain colour and preharvest sprouting-resistance in wheat
}

\author{
Manoel Carlos Bassoi(1) and John Flintham ${ }^{(2)}$ \\ (1)Embrapa Soja, Caixa Postal 231, CEP 86001-970 Londrina, PR, Brazil. E-mail: bassoi@cnpso.embrapa.br (2) John Innes Centre, Colney, \\ Norwich NR4 7UH, United Kingdom. E-mail: john.flintham@bbsrc.ac.uk
}

\begin{abstract}
Since red alleles $(R)$ of the genes that control grain colour are important for the improvement of preharvest sprouting resistance in wheat and there are three independently inherited loci, on chromosomes 3A, 3B and 3D of hexaploid wheat, it is possible to vary the dosage of dominant alleles in a breeding program. The objective of this work was to evaluate the dosage effect of $R$ genes on preharvest sprouting, in a single seed descent population, named TRL, derived from the cross between Timgalen, white-grained wheat, and RL 4137, red-grained wheat. The study was carried out using sprouting data in ripe ears obtained under artificial conditions in a rainfall simulator over three years. According to the results there is a significant effect on preharvest sprouting provided by colour and a weaker effect of increasing $R$ dosage. However, the significant residual genotypic variation between red lines and all lines (reds and whites) at $0.1 \%$ level showed that preharvest sprouting was also controlled by other genes. There are no significant correlations between sprouting and date of ripeness or between ripeness, $R$ dosage and colour intensity.
\end{abstract}

Index terms: Triticum aestivum, gene, allele, dormancy, dosage effect.

\section{Relação entre cor de grão e resistência à germinação pré-colheita em trigo}

\begin{abstract}
Resumo - Uma vez que os alelos dominantes para cor vermelha $(R)$, dos genes que controlam a cor do grão, têm importância no incremento da resistência à germinação pré-colheita, em trigo, e há três locos herdados independentemente, nos cromossomos 3A, 3B e 3D do trigo hexaplóide, é possível variar sua dosagem em um programa de melhoramento. O objetivo deste trabalho foi avaliar o efeito de dosagem dos genes $R$ na germinação précolheita, em uma população de descendência por semente única, batizada de TRL, derivada do cruzamento entre Timgalen, trigo de grão branco, e RL 4137, trigo de grão vermelho. O estudo utilizou dados de germinação em espigas maduras, obtidos sob condições artificiais em um simulador de chuva, em três anos. De acordo com os resultados, o efeito da cor de grão e, menos acentuadamente, da dosagem dos alelos dominantes, sobre a germinação pré-colheita foi significativo. Entretanto, a variação genotípica residual, entre as linhas vermelhas e entre as linhas vermelhas e brancas, significativa a 0,1\%, mostra que a germinação pré-colheita é também controlada por outros genes. Não foi constatada correlação significativa entre germinação na espiga e data de maturação ou entre maturação, dosagem de $R$ e intensidade de cor.
\end{abstract}

Termos para indexação: Triticum aestivum, gene, alelo, dormência, efeito de dosagem.

\section{Introduction}

In Brazil it is possible to grow two crops in each year. Wheat is sown in autumn, shortly after the summer harvest, and all cultivars are spring wheat. Modern Brazilian cultivars generally show little or no dormancy and very weak resistance to preharvest sprouting (PHS).

In the North and West regions of Paraná State, which are under subtropical conditions, harvest is in September and October. Those regions contribute to $60 \%$ of the overall country production. However, in South of Paraná and other states of Southern Brazil, namely Santa Catarina and Rio Grande do Sul, the harvest is in November. In all those regions, there are conditions conducive to PHS due to high temperatures and periodic rain. Derera (1990) reported cereal losses of US\$ 95 millions in 1988 due to preharvest rain in Brazil. In 1996, the wheat cultivar Embrapa 16, which in just two years had covered 11.8\% of wheat cultivated area in Paraná, was completely rejected for bread making because of PHS. In 1998, Embrapa 16 was sown on $1.5 \%$ of the total area of wheat in that State (Paraná, 1998). 
Wheat grain dormancy is a polygenic trait controlled by a set of three $R$ genes that control red testa pigmentation as well as by other genes. Among this second set there is at least one major gene expressing dormancy in the embryo. The existence of three independent loci for red colour and their association with grain dormancy was first postulated by Nilsson-Ehle (1914) and confirmed by numerous subsequent reports. Enhanced grain dormancy and red testa colour are inherited as pleiotropic effects of dominant $R$ alleles and represent a series of functionally equivalent genes, located at homeologous loci on chromosomes 3A, 3B and 3D of hexaploid wheat (Soper et al., 1989; Gale et al., 1995; Flintham \& Gale, 1996; Flintham et al., 1999; Flintham, 2000).

Preharvest sprouting in wheat is associated with inadequate seed dormancy and, consequently, red grain colour is a traditional marker for resistance to sprouting in wheat breeding programmes. On average, whitegrained wheats have been reported as more susceptible to sprouting than red wheats, although both groups vary. However, additional genetic effects, independent of seedcoat pigmentation, have been implicated in the control of dormancy in white and red wheats, reported by several authors (DePauw \& McCaig, 1983; Clarke et al., 1984; Mares, 1987; Flintham, 1993, 2000; Lawson et al.,1997; Wu \& Carver, 1999).

Flintham (2000) investigated the relationship between genotypic variation for dormancy and polymorphism for $R$ alleles among white and red near-isogenic lines, and genetic variation for dormancy between different redgrained varieties. In order to investigate the relationship between red and white-grained lines, five red-grained near-isogenic lines (NILs) were used, each one carrying a dominant $R$ allele from a different donor variety in the genetic background of the white-grained, spring-habit wheat Novosibirskaya 67, and additional NILs produced from the locally adapted (UK), white winter wheats varieties Abele, Holdfast and Wilma and from the breeder's line JBW.

Each white wheat was used as recurrent female parent for 22 independent sets of six serial backcrosses from their $F_{1}$ hybrids with the donor varieties Red Bobs, Chinese Spring, Cappelle Desprez and RL 4137. Genetic variation for dormancy between red-grained wheat varieties was investigated in 34 homozygous recombinant lines derived from $\mathrm{F}_{1}$ hybrids of Boxer $\mathrm{x}$ Soleil (bothR-A1b/R-B1b/R$D 1 b$ ) by the doubled-haploid method.
The results indicate that dominant $R$ alleles from diverse varieties all have functionally equivalent effects on dormancy, which are expressed via the seedcoat as a pleiotropic effect of red pigmentation. Further evidence suggests that different genetic backgrounds confer differential responses to the introgression of defined dominant $R$ alleles. Differences in genetic background also resulted in variation between the dormancy of two red wheats, both carrying three dominant $R$ alleles, and this variation can be assigned to a previously uncharacterized single major gene expressed in the embryo, for which the symbol Phs (preharvest sprouting) was proposed.

Since red alleles $(R)$ of the genes that control grain colour are important for the improvement of PHS resistance in wheat, and there are three independently inherited loci, on chromosomes $3 \mathrm{~A}, 3 \mathrm{~B}$ and $3 \mathrm{D}$ of hexaploid wheat, as described above, it is possible to vary the dosage of dominant alleles in a breeding program. According to the classical model, increasing dominant allele dosage should result in improvement of dormancy in red wheats (Nilsson-Ehle, 1914). Some evidence of such additive effects was described in a previous study of the TRL population by Flintham (1993), who used sprouting data in ripe ears obtained under artificial conditions in a rainfall simulator in 1991.

Sprouting data obtained in 1989 and 1990 under artificial conditions, together with that obtained in 1991, were analysed to study the relationships between $R$ dosage, grain colour, plant ripeness and sprouting in ripe ears.

\section{Material and Methods}

The TRL population (84 lines) is derived from the cross between Timgalen, which presents white colour of the seed coat with three recessive alleles $(R-A 1 a$, $R-B 1 a$ and $R-D 1 a$ ), and RL 4137, which presents red colour with three dominant alleles ( $R-A 1 b, R-B 1 b$ and $R-D 1 b)$. It was carried from $\mathrm{F}_{2}$ to $\mathrm{F}_{6}$ by line bulk selfing. From the $\mathrm{F}_{6}$ generation until $\mathrm{F}_{9}$, plants were derived by single seed descent (SSD) and a total of 90 recombinant inbred lines (RIL) were obtained, each derived from a different $F_{2}$ segregant. In the $F_{7}$ generation, each redgrained line was test-crossed using Timgalen as the recurrent parental. This test was performed in order to determine the number of dominant $R$ alleles carried by each RIL. 
The TRL population was obtained to develop several studies about preharvest sprouting in John Innes Centre (UK) and sprouting data were obtained under artificial conditions in a rain simulator (sprout chamber). That rain simulator is based on a Svalov design, in which overhead misty spray is applied to spikes held erect on perforated trays rotating at uniform speed in a chamber maintained at high relative humidity for seven days under continuous misting at $22-25^{\circ} \mathrm{C}$ (McMaster \& Derera, 1976).

Two tests were timed to maximize genetic variance, based on results from germination tests of the parents. Dormancy of parental seeds of this population was evaluated in Petri dish germination tests at $25^{\circ} \mathrm{C}$ at intervals after ripeness, starting immediately after harvest and every eight days thereafter. The TRL population was evaluated under simulated rainfall at the first time at which the susceptible parent (Timgalen) achieved $100 \%$ germination after 5 days in Petri dish test. The second simulated rain-test was performed when the resistant parent (RL 4137) achieved 50\% germination after five days in Petri dish test. Each time, the spikes remained seven days under continuous misting at $22-25^{\circ} \mathrm{C}$ in the sprout chamber. After each test, the spikes were threshed and 100 seeds per line were scored, using a 10x magnifying glass. Grain colour intensity was measured by visual observation scoring 1 (low) to 5 (high), using sodium hydroxide $(\mathrm{NaOH})$ to increase the contrast.

\section{Results and Discussion}

From 84 lines of the TRL population, 11 were white ( $r 1 r 2 r 3), 32$ carried a single gene for redness ( $R$ ? $r$ ? $r$ ?), 30 had two genes ( $R$ ? $R$ ? $r$ ?) and 11 had three genes ( $R 1 \quad R 2 R 3)$. These results were in agreement with the expected 1:3:3:1 Mendelian ratio, according to $\chi^{2}$ test.

The distribution of the sprouting averaged over three years is represented in Figure 1. The upper graph indicates the high difference between the means of red (\#R) and white-grained (W) groups, significant at the $0.1 \%$ level (Table 1 ). When the white-grained genotypes are removed from the data set, as showed in the red line graph, it is possible to observe the strong effect on sprouting provided by $R$ alleles (Figure 2). These results are in agreement with several reports (Soper et al., 1989; Flintham, 1993, 2000; Gale et al., 1995; Flintham \& Gale, 1996; Flintham et al., 1999). Figure 1 also indicates the differences between $R$ dosage group means ( $1 R$ vs. $2 R$ vs. $3 R$ ), significant at $5 \%$ level (Table 1 ), and between each $R$ dosage group and whitegrained group.

Considering only the $1 R$ dosage, the results are in agreement with Flintham (2000), who reported similar

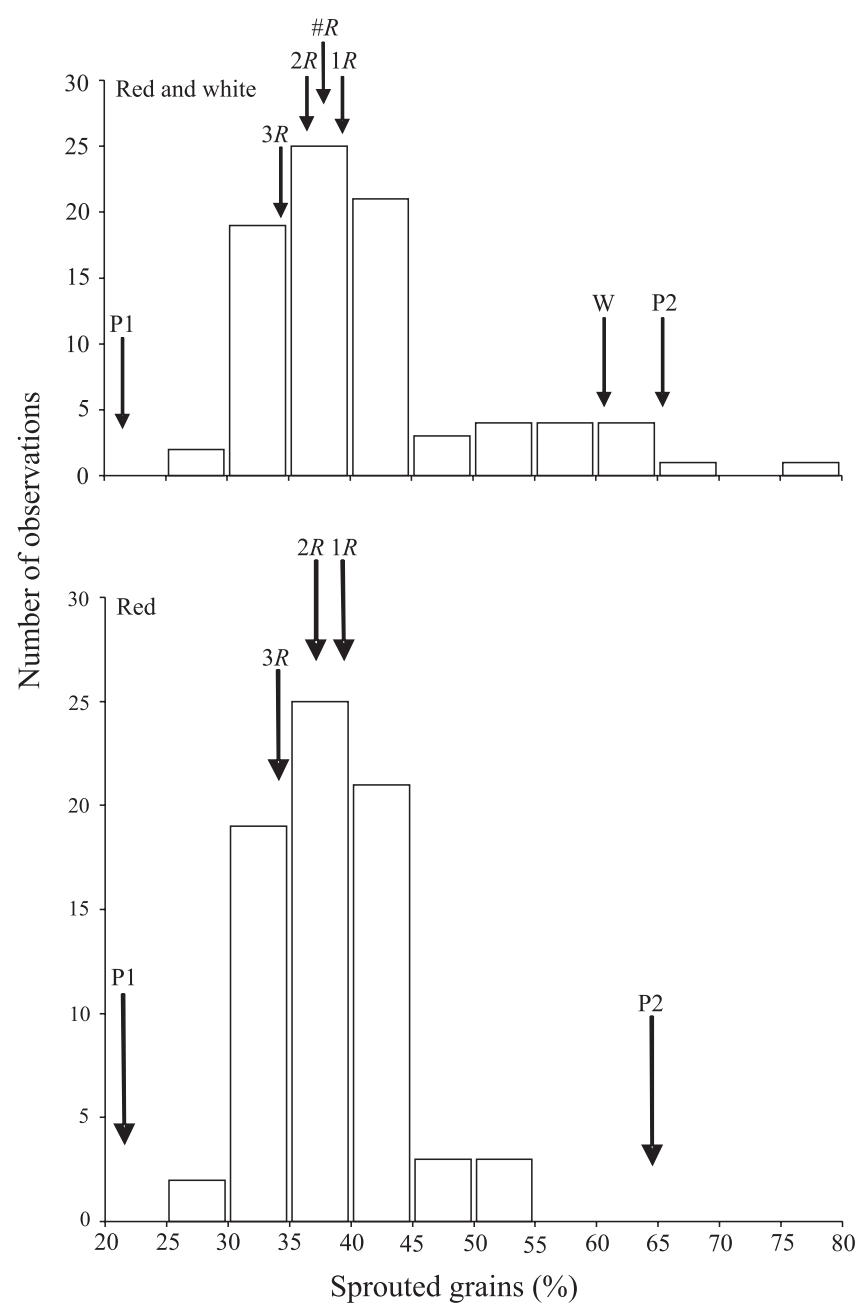

Figure 1. Average of sprouted grains, red and white and red grain lines, evaluated in 1989, 1990 and 1991 under artificial testing in the TRL population. Arrows indicate sprouting in P1: red-grained parent ( $R 1$ R2 R3); P2: white-grained parent ( $r 1$ r2 $r 3)$; $1 R$ : red-grained lines carried a single gene $(R$ ? $r$ ? $r$ ?); 2R: two genes ( $R$ ? $R$ ? $r$ ?); 3R: three genes (R1 R2 $R 3)$; $\# R$ : all red-grained lines; W: white-grained lines. Sprouting (\%) original data were transformed to arc sin. 
effects in red and white near-isogenic lines of different winter wheat varieties. In that case the genetic backgrounds were the same, just differing by single $R$ genes from different sources in each NIL. The genetic backgrounds found are different between the genotypes, as shown by the significant residual genotypic variation between red lines, and by significant genotypic variation in the $1 R$ dosage group (Table 1 ).

Among all 84 lines, the correlation coefficients between $R$ dosage (R\#) and sprouting in 1989, 1990, 1991 and the three years average are negative, relatively high and significant at the $1 \%$ level. Considering only the 73 red lines, the correlation coefficients decrease significantly, showing statistical significance at the $1 \%$ level in 1989 and in three years' average, but not significant in either 1990 or 1991 (Tables 2 and 3).

Among the red-grained-lines, increasing dosage of $R$ alleles was associated with small increases in resistance to sprouting (Figure 2). Averaged over three years, increasing $R$ dosage significantly increased dormancy of red-grained lines (Tables 1 and 3), however, this effect was not statistically significant in every individual year (Table 3).

The results showed the strong effect on sprouting provided by colour and $R$ dosage. However, the significant residual genotypic variation between red lines and between all lines (reds and whites), at $0.1 \%$ level (Table 1), shows that sprouting is also controlled by other genes.

In addition to the strong effect of $R$ alleles, the results also showed statistical significance among lines within each $R$ dosage group, including the white-grained lines.
Table 1 shows significant variance at the $0.1 \%$ level within white and $1 R$ groups, at the $1 \%$ level within $2 R$ group and at the $5 \%$ level within the $3 R$ group. These findings indicate possible improvement resistant to PHS, even in white-grained wheat lines, independent of by genes responsible for the seedcoat pigmentation.

As far as the correlation between years is concerned and considering the 84 lines, red and white-grained, there are highly significant correlation coefficients between years (Table 2), however, these are reduced among the red-grained lines (Table 3). These differences can be explained by the strong effect on sprouting provided by $R$ genes, which can minimize the influence of genotype $\mathrm{x}$ environment interaction. When the white-grained lines are excluded from the analysis and, consequently, the genetic variability is restricted to other genes in the background, possibly with additive and small effect, the genotype $x$ environment interaction has relatively greater effect. Analysis of variance in the TRL population showed a significant genotype $\mathrm{x}$ year interaction at the $0.1 \%$ level (Table 1 ). This interaction can bring serious implications for breeding programs to improve resistance to preharvest sprouting. This problem might be circumvented by identifying DNA markers for markerassisted selection.

The difference of colour intensity between whitegrained group and each of the $R$ dosage groups is very high, as expected. Among the $R$ dosage groups, the intensity of colour increases slightly but consistently and sprouting decreases in the same way for both traits (Table 4). As the increment in $R$ dosage can lead to PHS

Table 1. Analysis of variance in the TRL wheat population carried out in three years, showing the genotypic effect of the seed coat colour and gene number for red colour $(R)$ on sprouting. Sprouting (\%) original data were transformed to arc sin.

\begin{tabular}{|c|c|c|c|c|c|c|c|}
\hline Source of variation & Item & Df & SS & MS & F test & F value & EMS \\
\hline Year (y) & $\mathrm{Q}_{1}$ & 2 & $29,009.00$ & $14,504.50$ & $\mathrm{Q}_{1} / \mathrm{Q}_{13}$ & $616.43 * * *$ & $\mathrm{~V}_{\mathrm{e}}+84 \mathrm{~V}_{\mathrm{y}}$ \\
\hline Genotype x Year (gy) & $\mathrm{Q}_{2}$ & 166 & $11,918.57$ & 71.80 & $\mathrm{Q}_{2} / \mathrm{Q}_{13}$ & $3.05 * * *$ & $\mathrm{~V}_{\mathrm{e}}+\mathrm{V}_{\mathrm{gy}}$ \\
\hline Genotypes (g) & $\mathrm{Q}_{3}$ & 83 & $21,821.86$ & 262.91 & $\mathrm{Q}_{3} / \mathrm{Q}_{13}$ & $11.17 * * *$ & $\mathrm{~V}_{\mathrm{e}}+3 \mathrm{Vg}$ \\
\hline Reds (R) & $\mathrm{Q}_{4}$ & 72 & $6,041.37$ & 83.91 & $\mathrm{Q}_{4} / \mathrm{Q}_{13}$ & $3.57 * * *$ & $\mathrm{~V}_{\mathrm{e}}+3 \mathrm{~V}_{\mathrm{R}}$ \\
\hline $1 R$ & $\mathrm{Q}_{5}$ & 31 & $3,018.00$ & 97.35 & $\mathrm{Q}_{5} / \mathrm{Q}_{13}$ & $4.14 * * *$ & $\mathrm{~V}_{\mathrm{e}}+3 \mathrm{~V}_{1 R}$ \\
\hline $2 R$ & $\mathrm{Q}_{6}$ & 29 & $1,832.90$ & 63.20 & $\mathrm{Q}_{6} / \mathrm{Q}_{13}$ & $2.69 * *$ & $\mathrm{~V}_{\mathrm{e}}+3 \mathrm{~V}_{2 R}$ \\
\hline $3 R$ & $\mathrm{Q}_{7}$ & 10 & 554.18 & 55.42 & $\mathrm{Q}_{7} / \mathrm{Q}_{13}$ & $2.36^{*}$ & $\mathrm{~V}_{\mathrm{e}}+3 \mathrm{~V}_{3 R}$ \\
\hline $1 R$ vs $2 R$ vs $3 R(\mathrm{~d})^{(1)}$ & $\mathrm{Q}_{8}$ & 2 & 636.28 & 318.14 & $\mathrm{Q}_{8} / \mathrm{Q}_{9}$ & $4.12 *$ & $\mathrm{~V}_{\mathrm{e}}+3 \mathrm{~V}_{R}+59 \mathrm{~V}_{\mathrm{d}}$ \\
\hline Within $R$ dosage $(R)$ & $\mathrm{Q}_{9}^{(2)}$ & 70 & $5,405.08$ & 77.22 & $\mathrm{Q}_{9} / \mathrm{Q}_{13}$ & $3.28 * * *$ & $\mathrm{~V}_{\mathrm{e}}+3 \mathrm{~V}_{R}$ \\
\hline Whites (W) & $\mathrm{Q}_{10}$ & 10 & $1,556.73$ & 155.67 & $\mathrm{Q}_{11} / \mathrm{Q}_{13}$ & $6.62 * * *$ & $\mathrm{~V}_{\mathrm{e}}+3 \mathrm{~V}_{\mathrm{W}}$ \\
\hline Reds vs Whites (c) & $\mathrm{Q}_{11}$ & 1 & $14,223.76$ & $14,223.76$ & $\mathrm{Q}_{11} / \mathrm{Q}_{12}$ & $153.50 * * *$ & $\mathrm{~V}_{\mathrm{e}}+3 \mathrm{~V}_{\mathrm{R}+\mathrm{W}}+57 \mathrm{~V}_{\mathrm{c}}$ \\
\hline Within colour $(\mathrm{R}+\mathrm{W})$ & $\mathrm{Q}_{12}{ }^{(3)}$ & 82 & $7,598.10$ & 92.66 & $\mathrm{Q}_{12} / \mathrm{Q}_{13}$ & $3.94 * * *$ & $\mathrm{~V}_{\mathrm{e}}+3 \mathrm{~V}_{\mathrm{R}+\mathrm{W}}$ \\
\hline Error (e) & $\mathrm{Q}_{13}{ }^{(4)}$ & 24 & 564.83 & 23.53 & & & $\mathrm{~V}_{\mathrm{e}}$ \\
\hline Total & & 251 & $62,749.43$ & & & & \\
\hline
\end{tabular}

(1) $1 R$ : one dominant gene (red colour); $2 R$ : two dominant genes (red colour); 3R: three dominant genes (red colour). (2)Pool of $R$ dosage: SS $R=$ SS $1 R+$ SS $2 R+$ SS $3 R .{ }^{(3)}$ Pool of colour: SS $(\mathrm{R}+\mathrm{W})=$ SS R + SS W. ${ }^{(4)}$ Error was calculated using SS pool of parental lines over three years. $*$, ** and $* * *$ Significant at $5 \%, 1 \%$ and $0.1 \%$ level, respectively. 

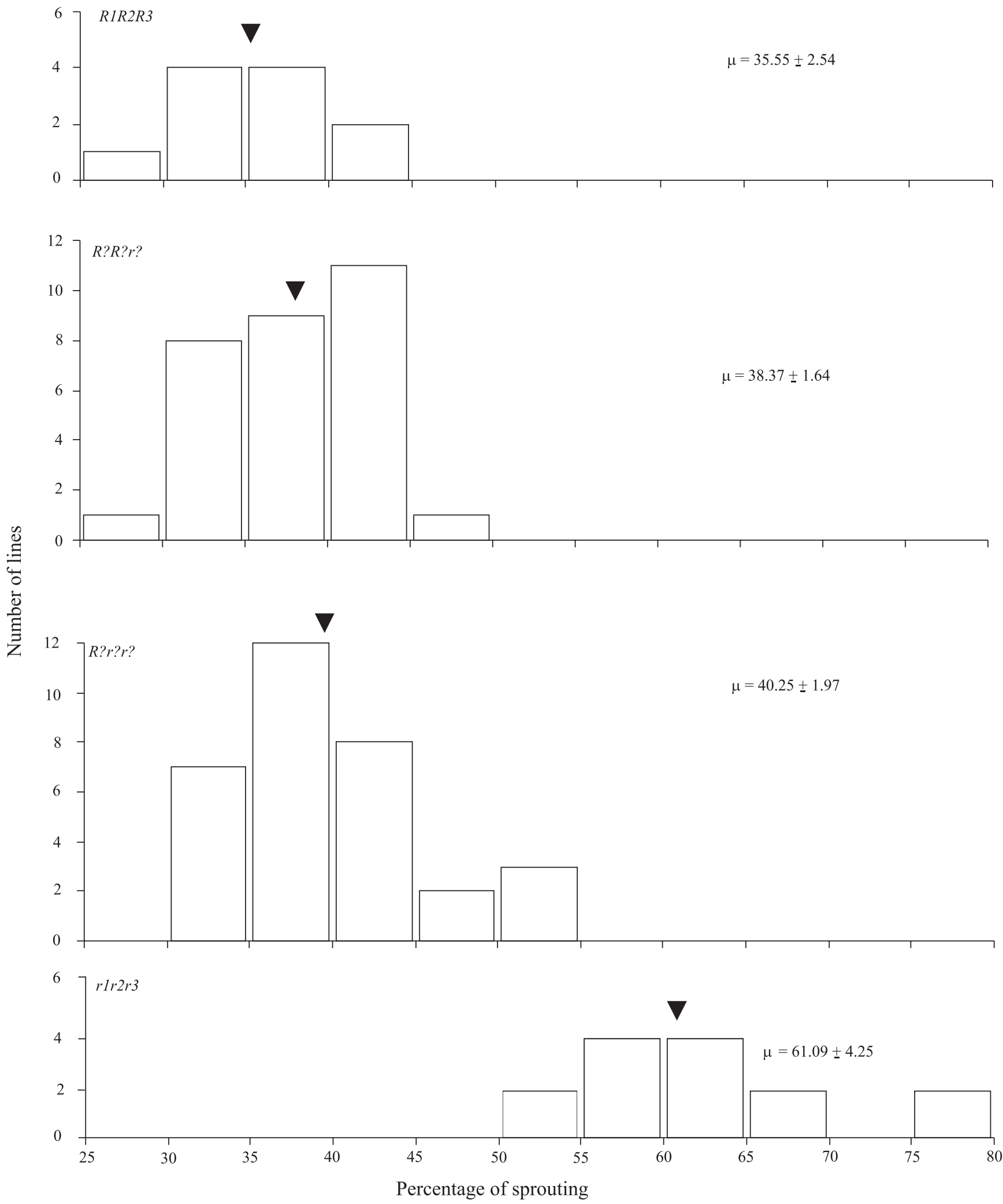

Figure 2. Increasing resistance to sprouting with increasing dosage of $R$ alleles in the TRL wheat population. Data represent sprouting average of 1989, 1990 and 1991. Arrowheads indicate mean of lines into each $R$ dosage group. Sprouting (\%) original data were transformed to arc sin. 
resistance, and increase the intensity of colour as well, it might be possible to use the latter as an index to select lines for PHS resistance. However, residual genotypic variation in intensity was detected within each $R$ dosage group (Figure 3), limiting the effectiveness of colour intensity as a selection index for increasing $R$ dosage. The correlation between intensity and sprouting score was of similar magnitude to that between $R$ dosage and sprouting score (-0.45 and -0.31 , respectively, Table 3$)$. Thus selection for increase in intensity of pigmentation

Table 2. Correlation coefficients among various traits based on 84 SSD wheat lines (Red and White) in the TRL population. Sprouting (\%) original data were transformed to $\operatorname{arc} \sin ^{(1)}$.

\begin{tabular}{lcccccc}
\hline Item & 1989 & 1990 & 1991 & Average & Colour & Ripeness \\
\hline R\# & $-0.68^{* *}$ & $-0.60^{* *}$ & $-0.50^{* *}$ & $-0.65^{* *}$ & $0.74^{* *}$ & $-0.03^{\text {ns }}$ \\
1989 & & $0.78^{* *}$ & $0.69^{* *}$ & - & $-0.76^{* *}$ & $-0.07^{\text {ns }}$ \\
1990 & & & $0.72^{* *}$ & - & $-0.74^{* *}$ & $-0.22^{*}$ \\
1991 & & & & - & $-0.67^{* *}$ & $-0.22^{*}$ \\
Average & & & & & $-0.79^{* *}$ & $-0.20^{\text {ns }}$ \\
Colour & & & & & & $0.03^{\text {ns }}$ \\
\hline
\end{tabular}

${ }^{(1)}$ R\#: number of the $R$ gene; 1989, 1990 and 1991: sprouting \% under artificial testing (Sprouting Chamber); Average: sprouting \% average of 1989, 1990 and 1991; Colour: visual observation of the seed coat colour in a 0 to 5 scale; Ripeness: visual observation of the loss of green pigments from the glumes or flag leaves in a 0 to 10 scale. * and **Significant at $5 \%$ and $1 \%$ level, respectively.

Table 3. Correlation coefficients among various traits based on 73 SSD wheat lines (Red) in the TRL population. Sprouting (\%) original data were transformed to $\operatorname{arc} \sin ^{(1)}$.

\begin{tabular}{lcccccc}
\hline Item & 1989 & 1990 & 1991 & Average & Colour & Ripeness \\
\hline R\# & $-0.40^{* *}$ & $-0.18^{\text {ns }}$ & $-0.16^{\mathrm{ns}}$ & $-0.31^{* *}$ & $0.48^{* *}$ & $-0.13^{\mathrm{ns}}$ \\
1989 & & $0.46^{* *}$ & $0.45^{* *}$ & - & $-0.41^{* *}$ & $-0.04^{\mathrm{ns}}$ \\
1990 & & & $0.43^{* *}$ & - & $-0.29^{*}$ & $-0.17^{\mathrm{ns}}$ \\
1991 & & & & - & $-0.40^{* *}$ & $-0.14^{\mathrm{ns}}$ \\
Average & & & & & $-0.45^{* *}$ & $-0.14^{\mathrm{ns}}$ \\
Colour & & & & & & $-0.11^{\mathrm{ns}}$ \\
\hline
\end{tabular}

(1)R\#: number of the $R$ gene; 1989, 1990 and 1991: sprouting \% under artificial testing (Sprouting Chamber); Average: sprouting \% average of 1989, 1990 and 1991; Colour: visual observation of the seed coat colour in a 0 to 5 scale; Ripeness: visual observation of the loss of green pigments from the glumes or flag leaves in a 0 to 10 scale. * and **Significant at $5 \%$ and $1 \%$ level, respectively.

Table 4. Colour mean and sprouting scores for TRL wheat population grouped by $R$ dosage. Sprouting (\%) data were transformed to arc sin.

\begin{tabular}{lcccc}
\hline Observations & \multicolumn{4}{c}{$R$ dosage } \\
\cline { 2 - 5 } & $r 1 r 2 r 3$ & $R ? r ? r ?$ & $R ? R ? r ?$ & $R 1 R 2 R 3$ \\
\hline Colour intensity & 0.9 & 3.3 & 3.9 & 4.2 \\
\% sprouting & & & & \\
1989 & 69 & 51 & 48 & 44 \\
1990 & 69 & 43 & 41 & 40 \\
1991 & 49 & 24 & 23 & 19 \\
Average & 61 & 40 & 38 & 35 \\
\hline
\end{tabular}

among red-grained segregants from a breeding cross should lead to improve resistance.

This study did not show significant correlations between sprouting and date of ripeness or between ripeness, $R$ dosage and intensity of colour, in either the whole TRL population or in 73 red-grained lines (Tables 2 and 3). However, it is difficult to draw firm conclusions about correlation between sprouting and ripeness, as all lines were harvested at the same time. In this case, some lines were kept in the field longer than others after physiological maturity. This might have been expected to lead to significant correlations between these traits, but no such correlations were observed.

According to several reports, different drying rates influenced by temperature, time and moisture, promote differences in alpha-amylase production and embryo germinability (Lush et al., 1981; Gale et al., 1983; King, 1993; Gordon, 1999; Lunn et al., 2001). Under field conditions such effects will be experienced at different physiological stages in genotypes which differ in ripening
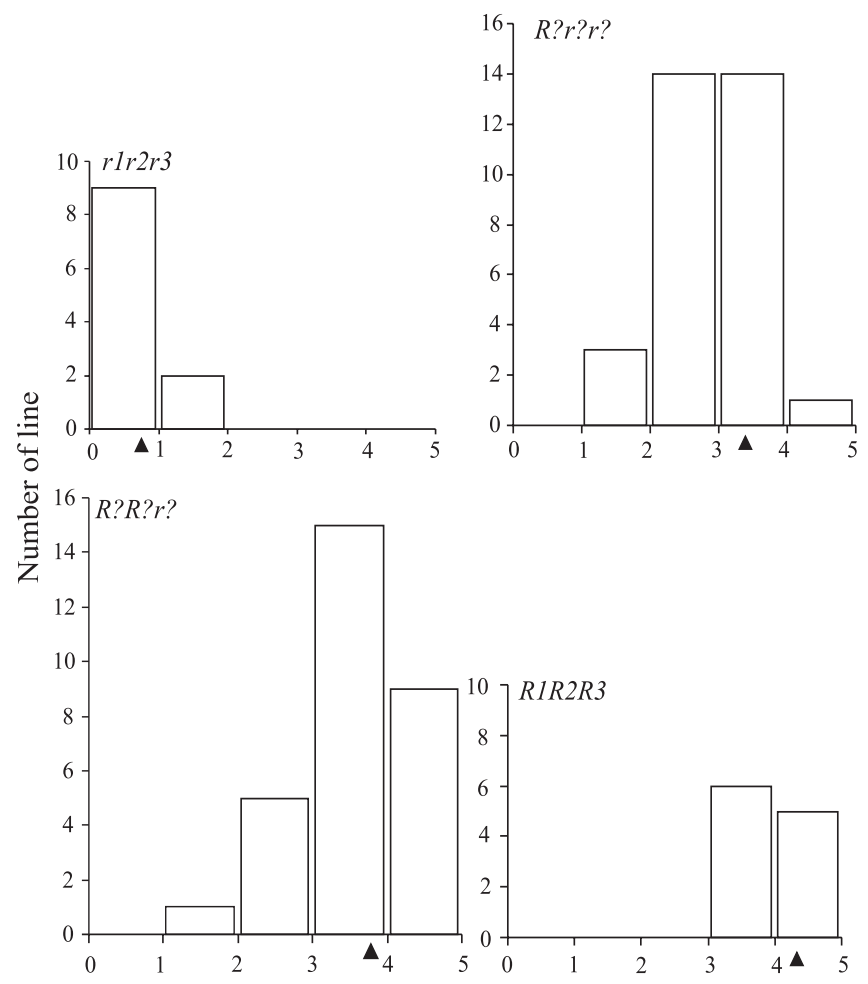

Figure 3. Depth of wheat seed coat colour determined with $\mathrm{NaOH}$. Arrowheads indicate means of colour intensity level into each $R$ dosage group. 
date. Variation in maturity might thus generate differences in dormancy via genotype $\mathrm{x}$ environment interaction (Reddy et al., 1985; Plett \& Larter, 1986; Hagemann \& Ciha, 1987; Kettlewell \& Astbury, 1990; Noda et al., 1993; Mares, 1993; Trethowan et al., 1996; Mrva \& Mares, 1996).

\section{Conclusions}

1. There is a strong effect on sprouting provided by colour and, to a lesser degree, by $R$ dosage.

2. When protection against preharvest sprouting is needed, selection of red-grained lines is effective.

3. Selection based on colour intensity by visual observation might not be efficient.

\section{Acknowledgements}

To Embrapa, Empresa Brasileira de Pesquisa Agropecuária, for awarding the first author a scholarship besides all the support needed.

\section{References}

CLARKE, J.M.; CHRISTENSEN, J.V.; DePAUW, R.M. Effect of weathering on falling numbers of standing and windrowed wheat. Canadian Journal of Plant Science, v.64, p.457-463, 1984.

DePAUW, R.M.; McCAIG, T.N. Recombining dormancy and white seed color in a spring wheat cross. Canadian Journal of Plant Science, v.63, p.581-589, 1983.

DERERA, N.F. Perspective of Sprouting Research. In: INTERNATIONAL SYMPOSIUM ON PRE-HARVEST SPROUTING IN CEREALS, 5., 1990, Boulder. Proceedings. Boulder: Westview, 1990. p.3-11.

FLINTHAM, J.E. Different genetic components control coatimposed and embryo-imposed dormancy in wheat. Seed Science Research, v.10, p.43-50, 2000.

FLINTHAM, J.E. Grain colour and sprout-resistance in wheat. In: INTERNATIONAL SYMPOSIUM PRE-HARVEST SPROUTING IN CEREALS, 6., 1993, St. Paul. Proceedings. St. Paul: American Association of Cereal Chemists, 1993. p.30-36.

FLINTHAM, J.E.; ADLAM, R.E.; GALE, M.D. Seedcoat and embryo dormancy in wheat. In: INTERNATIONAL SYMPOSIUM PRE-HARVEST SPROUTING IN CEREALS, 8., 1999, Detmold. Proceedings. Detmold: Association of Cereal Research and Federal Centre for Cereal; Potato and Lipid Research, 1999. p.67-76.

FLINTHAM, J.E.; GALE, M.D. Dormancy gene maps in homoeologous cereal genomes. In: INTERNATIONAL
SYMPOSIUM PRE-HARVEST SPROUTING IN CEREALS, 7., 1996, Osaka. Proceedings. Osaka: Center for Academic Societies, 1996. p.143-149.

GALE, M.D.; ATKINSON, M.D.; CHINOY, C.N.; HARCOURT, R.L.; JIA, J.; LI, Q.Y.; DEVOS, K.M. Genetic maps of hexaploid wheat. In: INTERNATIONAL WHEAT GENETICS SYMPOSIUM, 8., 1995, Beijing. Proceedings. Beijing: Agricultural Scientech, 1995. p.29-40.

GALE, M.D.; FLINTHAM, J.E.; ARTHUR, E.D. Alpha-amylase production in the late stages of grain development - an early sprouting damage risk period? In: INTERNATIONAL SYMPOSIUM PREHARVEST SPROUTING IN CEREALS, 3., 1983, Boulder. Proceedings. Boulder: Westview, 1983. p.29-35.

GORDON, I.L. GE interaction in wheat germinability. In: INTERNATIONAL SYMPOSIUM PRE-HARVEST SPROUTING IN CEREALS, 8., 1999, Detmold. Proceedings. Detmold: Association of Cereal Research and Federal Centre for Cereal; Potato and Lipid Research, 1999. p.224-230.

HAGEMANN, M.G.; CIHA, A.J. Environmental x genotype effects on seed dormancy and after-ripening in wheat. Agronomy Journal, v.79, p.192-196, 1987.

KETTLEWELL, P.S.; ASTBURY, J.M. Wheat grain drying rate and Hagberg falling number. In: INTERNATIONAL SYMPOSIUM ON PRE-HARVEST SPROUTING IN CEREALS, 5., 1990, Boulder. Proceedings. Boulder: Westview, 1990. p.85-91.

KING, R.W. Manipulation of grain dormancy in wheat. Journal of Experimental Botany, v.44, p.1059-1066, 1993.

LAWSON, W.R.; GOWIN, I.D.; COOPER, M.; BRENNAN, P.S. Genetic analysis of pre-harvest sprouting tolerance in three wheat crosses. Australian Journal of Agricultural Research, v.48, p.215221, 1997.

LUNN, G.D.; MAJOR, B.J.; KETTLEWELL, P.S.; SCOTT, R.K. Mechanisms leading to excess alpha-amylase activity in wheat (Triticum aestivum, L.) grain in the U.K. Journal of Cereal Science, v.33, p.313-329, 2001.

LUSH, W.M.; GROVES, R.H.; KAYE, P.E. Presowing hydration-dehydration treatments in relation to seed germination in early seedling growth of wheat and ryegrass. Australian Journal of Plant Physiology, v.8, p.409-425, 1981.

MARES, D.J. Pre-harvest sprouting in wheat. I. Influence of cultivar, rainfall and temperature during grain ripening. Australian Journal of Agricultural Research, v.44, p.1259-1272, 1993.

MARES, D.J. Pre-harvest sprouting tolerance in white grained wheat. In: INTERNATIONAL SYMPOSIUM PRE-HARVEST SPROUTING IN CEREALS, 4., 1987, Boulder. Proceedings. Boulder: Westview, 1987. p.64-74.

McMASTER, G.J.; DERERA, N.F. Methodology and sample preparation when screening for sprouting damage in cereals. Cereal Research Communications, v.4, p.251-254, 1976.

MRVA, K.; MARES, D.J. Inheritance of late maturity $\alpha$-amylase in wheat. Euphytica, v.88, p.61-67, 1996. 
NILSON-EHLE, H. Zur Kenntnis der mit der keimungsphysiologie des weizens in zusammenhang stehenden inneren faktoren. Zeitschrift für Planzenzüictung, v.2, p.153-187, 1914.

NODA, K.; KAWABAT, C.; KAWAKAMI, N. Wheat grain imbibition at low temperatures and embryo responsiveness to ABA. In: INTERNATIONAL SYMPOSIUM ON PRE-HARVEST SPROUTING IN CEREALS, 6., 1993, St. Paul. Proceedings. St. Paul: American Association of Cereal Chemists, 1993. p.367372.

PARANÁ: produção bruta e perspectiva de produção final de sementes de trigo - safra 1998. Curitiba: SEAB/DEFIS/DPSM, 1998. <www.pr.gov.br/seab/.>

PLETT, S.; LARTER, E.N. The influence of maturation temperature and stage of kernel development on sprouting tolerance of wheat and triticale. Crop Science, v.26, p.804-807, 1986.
REDDY, L.V.; METZGER, R.J.; CHING, T.M. Effect of temperature on seed dormancy of wheat. Crop Science, v.25, p.455-458, 1985. SOPER, J.F.; CANTRELL, R.G.; DYCK, J.W. Sprouting damage and kernel color relationship in durum wheat. Crop Science, v.29, p.895-898, 1989.

TRETHOWAN, R.M.; RAJARAM, S.; ELLISON, F.W. Pre-harvest sprouting tolerance of wheat in the field and under rain simulation. Australian Journal of Agricultural Research, v.47, p.705-716, 1996.

WU, J.; CARVER, B.F. Sprout damage and pre-harvest sprout resistance in hard white winter wheat. Crop Science, v.39, p.441447, 1999.

Received on May 4, 2004 and accepted on March 31, 2005 